\title{
Floristic diversity in the transition from traditional to modern land-use in southern Sweden A.D. 1800-2008
}

\author{
Daniel Fredh • Anna Broström • Lovisa Zillén • \\ Florence Mazier • Mats Rundgren • \\ Per Lagerås
}

Received: 19 August 2011/Accepted: 15 March 2012/Published online: 11 April 2012

(C) The Author(s) 2012. This article is published with open access at Springerlink.com

\begin{abstract}
We aim to provide a long-term ecological analysis of land-use and floristic diversity in the transition from traditional to modern land-use management in the time A.D. 1800-2008 in southern Sweden. We use the Regional Estimates of Vegetation Abundance from Large Sites (REVEALS) model to quantify land-cover changes on a regional scale at 20 -year intervals, based on the fossil pollen record. Floristic richness and evenness are estimated using palynological richness and the Shannon index applied to the REVEALS output, respectively. We identified a transition period of 60 years between 1880 and 1940 when the total tree cover increased and the tree composition changed from deciduous to coniferous dominance. Within the shrinking area of open land, arable land taxa expanded, while the number and coverage of herbs in the remaining grasslands decreased. The succession from open grasslands to more tree-covered habitats initially favoured palynological richness, which reached its highest values during the first 40 years of the transition period. The highest REVEALS-based evenness was recorded in the time of traditional land-use and at the beginning of the transition period, reflecting higher habitat diversity at
\end{abstract}

Communicated by A.F. Lotter.

D. Fredh $(\bowtie) \cdot$ A. Broström · L. Zillén · M. Rundgren

Department of Geology, Quaternary Sciences, Lund University, Sölveg. 12, 22362 Lund, Sweden

e-mail: daniel.fredh@geol.lu.se

F. Mazier

GEODE, UMR 5602, University of Toulouse-Le Mirail, 5 allées

A. Machado, 31058 Toulouse Cedex, France

P. Lagerås

Swedish National Heritage Board, Archaeological Excavations Department UV Syd, Odlarevägen 5, 22660 Lund, Sweden these time intervals. Our results support a more dynamic ecosystem management that changes between traditional land-use and phases of succession ( $<40$ years) to promote floristic diversity. We have developed and applied a palaeoecological methodology that contributes realistic estimates to be used in ecosystem management.

Keywords Ecosystem management · Floristic diversity · Land-use transition · Pollen analysis · Quantitative reconstruction $\cdot$ REVEALS model

\section{Introduction}

The Convention of Biological Diversity has agreed upon a new strategy for 2020 including 20 biodiversity targets to be implemented internationally, which will eventually modify the European environmental objectives. For this purpose we need to develop integrated science-based ecosystem management tools for biodiversity assessment which use multiple sources of information and approaches including direct observations, palaeoecological records, experiments, climate models, mechanistic ecophysiological models and population models (Dawson et al. 2011). Although possible future climates and land-use will most likely be very different from those of the past, palaeoecological records offer essential information about rates and degrees of vegetation change (Jackson and Hobbs 2009; Haslett et al. 2010; Willis et al. 2010; Willis and Bhagwat 2010).

Traditional land-use during the last millennia in Europe has led to a landscape with high biodiversity (Berglund 1991; Emanuelsson 2009). However, the transition to modern land-use management in the last century has allowed only small parcels of habitats related to traditional 
cultural landscapes to remain. These remaining habitats, in particular those with high biodiversity, have, over the last few decades, been the focus for nature conservancy efforts (Eriksson et al. 2002; Poschlod et al. 2005; Plieninger 2006; Emanuelsson 2009). Several of these habitats, for example semi-natural grasslands and woodlands, have recently been recognized, according to the concept of ecosystem services, as providing various services to humanity, such as services which provide resources such as of food and timber and cultural resources such as aesthetic values and recreation (MA 2005; Harrison et al. 2010). The nature conservancy management of these areas has predominantly been through continuous land-use, such as over-grazing of meadows and pastures, or by leaving seminatural woods unmanaged, and has led to a decrease in diversity in both flora and fauna (Plieninger 2006; Dahlström and Hallgren 2008). To maintain high biodiversity we need a dynamic management approach that takes into account ecosystem change in space and time (Anton et al. 2010; Haslett et al. 2010). The traditional cultural landscape was highly dynamic with changes in land-use management at various temporal and spatial scales, for example abandonment of non-permanent fields/grasslands or of whole farms during times of crisis, but our understanding of the influence of this management practice on floristic diversity in the long term is far from complete (Johansson et al. 2008; Emanuelsson 2009; Haslett et al. 2010). However, palaeoecological records may provide the relevant timescales in decades or millennia for understanding long-term ecological processes which are important to biodiversity (Willis et al. 2010).

So far, landscape development in northern Europe over the last few hundred years has been studied mainly using historical documents and maps (Eriksson et al. 2002; Bender et al. 2005; Lunt and Spooner 2005; Zimmermann et al. 2010). These historical data sources can be used to estimate the spatial extent of cultivated fields, meadows and common lands, but seldom provide compositions of taxa in different land-use types. Moreover, the historical data are highly heterogeneous in temporal and spatial coverage and cannot provide a continuous record of quantified past land-use and floristic diversity on a regional and local scale.

On the other hand, pollen-based reconstructions, using fossil pollen extracted from lake or bog sediments, may provide continuous information on past changes of taxa composition. However, the non-linear nature of the relationship between vegetation abundance and pollen proportion in sediments has made it difficult to quantify vegetation cover based on pollen data (Broström et al. 1998; Sugita et al. 1999; Hellman et al. 2009). Many tree taxa are in general overrepresented and many herb taxa are often underrepresented in pollen assemblages compared to their abundance in the surrounding vegetation (Bradshaw and Webb 1985;
Broström et al. 1998; Sugita et al. 1999; Davis 2000). As a consequence, the quantitative reconstruction of landscape openness, as in woodland clearings, grasslands and cultivated fields is not straightforward. However, palaeoecological methodologies have advanced in recent years especially in regard to the quantification of past vegetation change (Gaillard et al. 2010), the Landscape Reconstruction Algorithm (LRA) (Sugita 2007a, b). LRA is designed to correct for pollen representation biases and to quantify vegetation composition based on fossil pollen assemblages (Sugita 2007a, b). LRA with submodel Regional Estimates of Vegetation Abundance from Large Sites (REVEALS) uses pollen assemblages from large ( $\geq 100-500$ ha) lakes to quantify vegetation composition at a regional scale $\left(10^{4}-10^{5} \mathrm{~km}^{2}\right)$ (Sugita 2007a). These new tools for modelling vegetation composition of past landscapes rely on a theoretical framework (Davis 1963; Andersen 1970; Parsons and Prentice 1981; Prentice 1985; Sugita 1993), simulations (Sugita 1994; Sugita et al. 1999), and on studies of the relationship between surface pollen assemblages and modern vegetation (Broström et al. 1998). Simulations and empirical studies have shown that site to site variation in pollen loading between large lakes within a region is small and that the pollen compositions in the sediments from such lakes correspond to the regional vegetation cover (Sugita 1994; Hellman et al. 2008b). The REVEALS model has been empirically validated in Sweden, Switzerland and the USA (Hellman et al. 2008b; Soepboer et al. 2010; Sugita et al. 2010). Importantly, taxon-specific pollen productivity estimates (PPEs), which are crucial for REVEALS-based vegetation reconstruction, are now available for several areas in Europe (Broström et al. 2008) and North America (Calcote 1995). The REVEALS model has been used for past land-cover estimates on a regional scale inferred from fossil pollen records in southern Sweden and Switzerland (Sugita et al. 2008; Soepboer et al. 2010) and currently for multiple sites on a subcontinental European scale (Gaillard et al. 2010).

When studying the modern landscape, floristic diversity can be measured by counting the number of species (species richness) within an area. However, this measure is not usually enough to describe the biodiversity in an area, as the relative abundances of species is also of great importance for estimates of biodiversity, and therefore evenness is often used as a measure of the distribution of species in a biological community (species evenness) (Magurran 2004). High evenness corresponds to equal spatial distribution of taxa, and low evenness represents dominance by a few taxa within a given area. Reconstructions of past floristic diversity have so far been restricted to palynological richness as a proxy for species richness, that is the number of pollen taxa found in a sample, and by using rarefaction analysis, samples in a sequence can be compared despite differences in the total amount of pollen counted in each 
sample (Birks and Line 1992; Odgaard 1999; Berglund et al. 2008; Sköld et al. 2010). Estimates of past floristic evenness have rarely been attempted before due to the difficulties in understanding how the pollen record represents the surrounding vegetation, for example due to differences in pollen productivity between taxa (Odgaard 1994, 1999). Despite these difficulties, it has been suggested that there may be a relationship between palynological evenness and the surrounding vegetation (Odgaard 2007). However, this relationship is still unknown, and therefore evenness indices applied to the corrected vegetation proportions estimated by the REVEALS model (REVEALS-based evenness) is probably at present the best method to reconstruct past vegetation evenness, because the model corrects for all known major biases in pollen representation of vegetation. In this way REVEALS-based evenness may be used in addition to palynological richness to provide a more complete reconstruction of past floristic diversity.

In this study we use the landscape in southern Sweden as an example representative of northwest Europe and the aims are to:

- Analyse the relationship between land-use and floristic diversity in the transition from traditional to modern land-use management between A.D. 1800 and 2008.

- Apply pollen analysis and the REVEALS model to the quantification of changes in land-cover, land-use and floristic diversity based on lake sediment pollen records. The spatial scale is regional (within a $50 \mathrm{~km}$ radius) and the time resolution is 20-year intervals.

- Develop a method for estimating past floristic diversity using a combination of palynological richness analysis and new ways of estimating past floristic evenness.

- Provide quantification of change in land-use with time that promotes floristic diversity useful for ecosystem management.

\section{Study area}

Our study is based on a lake sediment sequence from Fiolen (160 ha), situated in the upland area of southern Sweden, here defined as the area above $200 \mathrm{~m}$ a.s.l. (Fig. 1). The lake is situated within a nature reserve, Fiolenområdet, consisting of arable fields and woods and has been the object of limnological research since 1928. Settlements around the lake have been present at least since medieval times (Larsson 1980).

The study area is part of the boreo-nemoral zone characterized by a mixture of coniferous and deciduous woods, with Picea and Pinus as the dominant trees (Sjörs 1963). The tree cover is ca. $72 \%$, shrubs ca. $1 \%$, herbs ca. $21 \%$

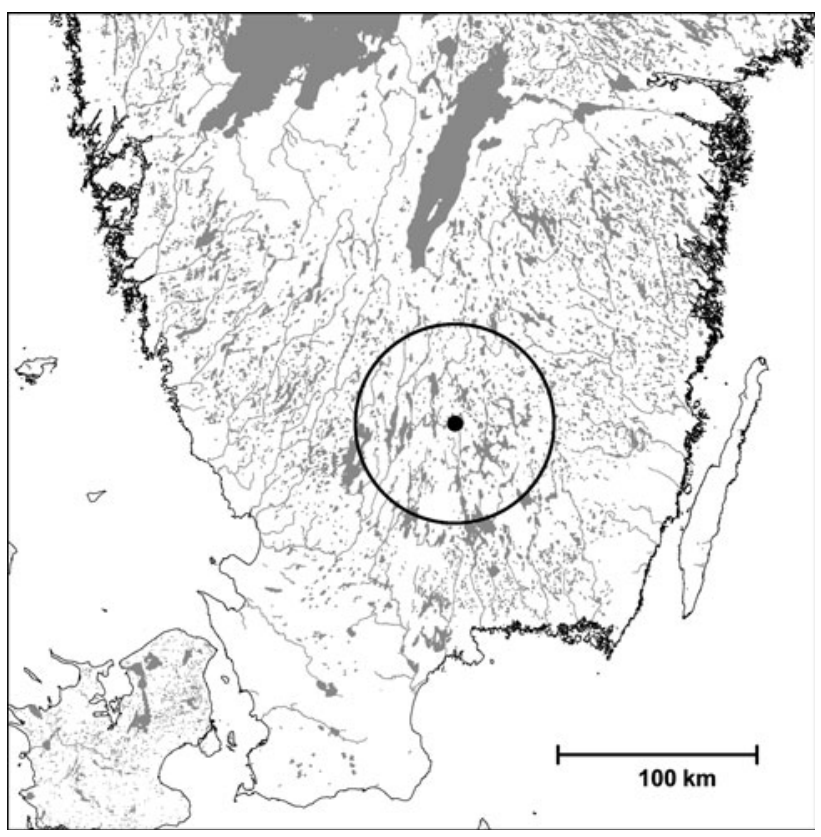

Fig. 1 Location of Fiolen (black dot) in the upland area of southern Sweden and maximum extent of regional vegetation $(z$ max) from where the main parts of the pollen assemblages are derived (circle with $50 \mathrm{~km}$ radius)

and Cerealia (including Secale) ca. 6\% (Hellman et al. 2008b). Land-use is dominated by forestry, but grass and crop cultivation occur on the most suitable soils. Mean annual temperatures are $5-7^{\circ} \mathrm{C}$, and mean annual precipitation varies from ca. 600 to ca. $1,200 \mathrm{~mm}$ on an east-west gradient (Raab and Vedin 1995). The geological setting is characterized by crystalline granitic bedrock and gneisses covered by sandy till and occasional glacifluvial deposits (Fredén 1994).

Because of their relatively poor soil conditions, uplands are usually less suitable for agriculture compared to lower areas and they were therefore colonized relatively late (Berglund et al. 2002; Poschlod et al. 2005). For the same reason, uplands are expected to be more sensitive to population changes. This is supported by evidence from the late medieval agrarian crises, when farms in the marginal areas were abandoned and the population was concentrated in areas with the best soils (Myrdal 2003; Emanuelsson 2005; Lagerås 2007).

From ca. A.D. 1000, agriculture in the upland area was dominated by permanently farmed land, with clear separation between cultivated fields, meadows and common land around the farms (Berglund et al. 2002). During the agricultural revolution (ca. 1700-1900) arable fields were combined to form larger units, and the common land was split up and divided between farmers (Gadd 2000). Each farm thereby had more influence on its lands, with the result that the common land was often planted with Picea and the cultivated fields were expanded (Morell 2001). 
This became possible with the introduction of fertilizers and grass cultivation, which made it no longer necessary to maintain the previous balance between the area of meadows used for hay making and the number of animals providing manure for the fields. The maximum extent of grasslands in Sweden was around 1880, and cultivated fields were most extensive around 1920 (Morell 2001). The effect of urbanization is clearly seen from the late 19th century, when the rural Swedish population decreased rapidly despite an increase in the total population (Andersson Palm 2000). Consequently, the upland area in southern Sweden is well-suited for studying the effect of past land-use changes.

\section{Methods}

Fieldwork and subsampling

Two overlapping sediment cores, consisting of brown fine detritus gyttja, were retrieved from the bottom of the lake using Kajak (Renberg and Hansson 2008) and piston corers for upper and lower sediment cores, respectively in June 2008. The upper sediment core $(0-0.45 \mathrm{~m}$ depth $)$ was sliced in contiguous $0.5 \mathrm{~cm}$ subsamples in the field, while the lower sediment core $(0.20-4.70 \mathrm{~m}$ depth) was sealed before transport and further subsampling in the laboratory. Subsamples from the sediment cores were taken out at various intervals for analysis of fossil pollen composition, spheroidal carbonaceous particle (SCP) content, mineral magnetic parameters, X-ray fluorescence (XRF), total organic carbon (TOC) and lead-210 dating.

\section{Lead-210 dating}

Lead-210 $\left({ }^{210} \mathrm{~Pb}\right)$ dating was used to establish a sediment chronology for the last ca. 150 years and the chronology was used to calculate an age for each subsample taken out from the sediment cores. 26 samples were analysed for the activity of ${ }^{210} \mathrm{~Pb}$ and ${ }^{226} \mathrm{Ra}$ (21 from the upper and five from the lower core) in the uppermost part of the sequence (0-0.44 m depth). The samples were analysed via gamma spectrometry at the Gamma Dating Centre, Institute of Geography at the University of Copenhagen, Denmark, on a Canberra low-background Germanium well-detector. The ${ }^{210} \mathrm{~Pb}$ deposited on the lake from the atmosphere and used in subsequent analysis, the unsupported ${ }^{210} \mathrm{~Pb}$, was calculated based on the ${ }^{226} \mathrm{Ra}$ measurements in each sample. Five samples with relatively low values and one sample with a relatively high value were assumed to be outliers and were rejected in the subsequent analysis. Constant Rate of Supply (CRS) modelling (Appleby 2001) was applied to the combined profile from the two overlapping cores to create an age/depth model and to calculate error estimates based on the ${ }^{210} \mathrm{~Pb}$ measurements. Below $35 \mathrm{~cm}$ the activity of ${ }^{210} \mathrm{~Pb}$ was calculated by assuming a constant sedimentation rate (Appleby 2001). The age of each sample was calculated using linear interpolation between ${ }^{210} \mathrm{~Pb}$ dated levels. The chronology was extended back to A.D. 1800 based on the mean accumulation rate at the two lowermost ${ }^{210} \mathrm{~Pb}$ dated levels obtained from the CRS modelling. Extrapolation also took into account bulk density data to compensate for increasing compaction downwards in the sediment sequence.

\section{Mineral magnetism}

Mineral magnetic measurements of lake sediment sequences are often used in studies related to past environmental changes, such as the effects of land-use changes on lake ecosystems (Thompson et al. 1980). Here we used standard mineral magnetic techniques to facilitate the correlation between the upper and lower sediment cores. For this purpose, the ratio (S-ratio) between the Saturation Isothermal Remanent Magnetization (SIRM) and the Backfield Isothermal Remanent Magnetisation (IRM) (Thompson and Oldfield 1986) was in this study found to be the most significant parameter. Mineral magnetic parameters were measured on contiguous $0.5 \mathrm{~cm}$ samples of fresh sediment at the Palaeomagnetic and Mineral Magnetic Laboratory at Lund University. The samples were magnetised with a Redcliffe 700 BSM pulse magnetiser in a field of 1 Tesla, after which SIRM was measured with a Molspin Minispin (MM) magnetometer. IRM (magnetic field of $-100 \mathrm{mT}$ ) was induced with a high-resolution pulse magnetizer (Molspin) and subsequently measured on the MM magnetometer. The dry mass of each sample was measured after oven drying at $40^{\circ} \mathrm{C}$ to enable calculation of mass specific SI units.

\section{Chronological markers}

Several known events during recent centuries have had an impact on the environment and have left markers in the lake sediments. Here, we used total lead concentrations and spheroidal carbonaceous particles (SCP) as chronological markers to validate the chronology (Wik and Renberg 1996; Brännvall et al. 2001; Renberg et al. 2001). Both these markers are related to the burning of fossil fuels in transport and industry. Lead was measured at each $1 \mathrm{~cm}$ interval in the upper sediment core and between 1 and $11 \mathrm{~cm}$ intervals in the lower sediment core with X-ray fluorescence (XRF) at the Environmental Magnetism Laboratory at the department of Geography, Liverpool University, UK, using an S2 ranger. Element concentrations for each sample were calculated using machine-specific software in combination with a set of standards and 
the total organic content (TOC) in each sample. TOC was analysed using a Costech ECS 4010 elemental analyser at Lund University. SCP $(<50 \mu \mathrm{m})$ were counted simultaneously with pollen on each slide (contiguous $0.5 \mathrm{~cm}$ ) and due to low counts added together for each $5 \mathrm{~cm}$ interval.

Pollen analysis

For the pollen analysis $1 \mathrm{cc}$ of material was sampled every $0.5 \mathrm{~cm}$ in the sediment cores $(0-44 \mathrm{~cm}$ sediment depth from the upper core and below $44 \mathrm{~cm}$ from the lower core) from which pollen grains were extracted using standard methods (Berglund and Ralska-Jasiewiczowa 1986). Pollen grains were identified using a light microscope, the reference collection at Lund University, and identification keys (Beug 1961; Punt 1976-2003; Moore et al. 1991). For the target taxa at least 1,000 pollen grains were counted for each 20-year time interval, which was inferred from the

Table 1 Fall speed of pollen, relative pollen productivity estimates (PPE) and standard error estimates (SE) for 25 taxa obtained for southern Sweden (Sugita et al. 1999; Broström et al. 2004) and Denmark (numbers in bold; Nielsen 2004) used in the REVEALS model run

\begin{tabular}{llll}
\hline & Fall speed $(\mathrm{m} / \mathrm{s})$ & PPE & SE \\
\hline Acer & 0.056 & 1.267 & 0.452 \\
Alnus & 0.021 & 4.200 & 0.140 \\
Betula & 0.024 & 8.867 & 0.134 \\
Calluna vulgaris & 0.038 & $\mathbf{1 . 1 0 2}$ & $\mathbf{0 . 0 5 4}$ \\
Carpinus & 0.042 & 2.533 & 0.070 \\
Cerealia type & 0.060 & $\mathbf{0 . 7 4 7}$ & $\mathbf{0 . 0 3 9}$ \\
Asteraceae SF. Cichorioideae & 0.051 & 0.244 & 0.065 \\
Corylus & 0.025 & 1.400 & 0.042 \\
Cyperaceae & 0.035 & 1.002 & 0.164 \\
Fagus & 0.057 & 6.667 & 0.173 \\
Filipendula & 0.006 & 2.480 & 0.821 \\
Fraxinus & 0.022 & 0.667 & 0.027 \\
Juniperus & 0.016 & 2.067 & 0.036 \\
Picea & 0.056 & 1.757 & 0.000 \\
Pinus & 0.031 & 5.663 & 0.000 \\
Plantago lanceolata & 0.029 & $\mathbf{0 . 8 9 7}$ & $\mathbf{0 . 2 3 5}$ \\
Poaceae & 0.035 & 1.000 & 0.000 \\
Quercus & 0.035 & 7.533 & 0.083 \\
Ranunculus acris type & 0.014 & 3.848 & 0.718 \\
Rubiaceae & 0.019 & 3.946 & 0.589 \\
Rumex acetosa type & 0.018 & $\mathbf{1 . 5 5 9}$ & $\mathbf{0 . 0 8 9}$ \\
Salix & 0.022 & 1.267 & 0.313 \\
Secale type & 0.060 & 3.017 & 0.052 \\
Tilia & 0.032 & 0.800 & 0.029 \\
Ulmus & 0.032 & 1.267 & 0.050 \\
\hline & & & \\
& & & \\
& & &
\end{tabular}

chronology (Table 1). The total pollen count varied between 1,220 and 1,882. We estimated that a 20-year time resolution is high enough to capture several potentially registered changes in land-use and vegetation which are known to have occurred during the last 200 years, but not too high to capture the weather induced year-to-year variation in pollen productivity (Hicks 1999; Autio and Hicks 2004). Due to a relatively high sedimentation rate $(<8 \mathrm{~mm} /$ year), pollen grains from several $0.5 \mathrm{~cm}$ intervals $(5-17)$ were counted to add up to a 20 -year interval. The 1,000 pollen grains were equally divided between these intervals resulting in counting between ca. 60 and 200 grains per pollen slide. Separation of Cerealia type and Secale type from wild grass pollen was based on size measurements of the grain and the pore (Cerealia: grain $>37 \mu \mathrm{m}$, pore $>8 \mu \mathrm{m}$ ), and examination of the exine sculpture using phase contrast microscopy (Beug 2004).

\section{Reconstructions of floristic richness and evenness}

Floristic richness was estimated using palynological richness, the number of different pollen and spore taxa found in each sample (Birks and Line 1992). Based on all terrestrial taxa found in the pollen sequence, in total 16 trees, 41 herbs and 7 ferns, the rarefaction, which is used to estimate the number of taxa $\left[E\left(T_{n}\right)\right]$ for a constant counting sum, was calculated for each time window to compensate for biases due to differences in number of pollen grains counted in each sample using the formula:

$E\left(T_{n}\right)=\sum_{i=1}^{T} 1-\left[\frac{\left(N-N_{i}\right) !(N-n) !}{\left(N-N_{i}-n\right) ! N !}\right]$

where $E\left(T_{n}\right)$ is the expected number of taxa for a standardised pollen count $n$ (the smallest total pollen sum between samples being compared). $T$ is the number of taxa in the original pollen count, $N_{i}$ is the number of pollen grains assigned to taxon $i$ in the original pollen count and $N$ is the total pollen count (Birks and Line 1992).

Floristic evenness was estimated for each time interval using the ratio $(\mathrm{J})$ between Shannon index $(\mathrm{H})$ and maximum evenness, when all taxa are equally frequent $\left(H_{\max }\right)$. This method was applied to the proportional abundances estimated by REVEALS (Magurran 2004; Sugita 2007a). REVEALS-based evenness is a new method to reconstruct past floristic evenness on a regional scale based on the REVEALS model output, on taxa for which PPEs are available, 14 tree and 11 herb taxa in this study. For comparison, we also calculated evenness based on the raw pollen counts (palynological evenness) both for all 64 identified terrestrial pollen taxa and for the same 25 taxa that were used to calculate the REVEALS-based evenness. The Shannon index $(\mathrm{H})$ is: 
$H=\left(-\sum_{i=1}^{i=q} p_{i} \log p_{i}\right)$

where $p_{i}$ is the proportion of taxon $i$ and $q$ is the number of taxa (Magurran 2004; Odgaard 2007). Maximum evenness $\left(H_{\max }\right)$, when all taxa are equally frequent, is equal to $\log q$. The ratio $J$ between $H$ and $H_{\max }$ is used to calculate evenness (Magurran 2004; Odgaard 2007):

$J=H / H_{\max }=\frac{H}{\log q}$

Quantitative reconstructions of land cover using the REVEALS model

In theory, pollen that is deposited in large lakes $(\geq 100-500 \mathrm{ha})$ originates from the regional vegetation $\left(10^{4}-10^{5} \mathrm{~km}^{2}\right)$ (Sugita 1994, 2007a), which has been tested by simulations and empirical studies (Sugita 1994; Hellman et al. 2008b). The pollen assemblages in sediment sequences for a specific time from large lakes in a region are therefore similar. However, it is difficult to infer the actual vegetation based solely on pollen assemblages from such lakes due to differences in pollen productivity and dispersal characteristics between taxa, and the non-linear relationship between pollen deposited at a site and surrounding vegetation (Sugita 1994; Broström et al. 1998; Sugita et al. 1999; Davis 2000; Sugita 2007a). The REVEALS model is an objective way to estimate regional vegetation composition by using a mathematical approach that compensates for known biases in how vegetation is represented in the pollen record (Sugita 2007a).

Based on pollen counts for each 20-year interval, we used the REVEALS program (v4.2.2) to provide quantitative estimates of vegetation composition at a regional scale, within $50 \mathrm{~km}$ radius, between 1800 and 2008. We applied PPEs obtained from southern Sweden (Sugita et al. 1999; Broström et al. 2004), except for Calluna vulgaris, Cerealia type, Plantago lanceolata and Rumex acetosa type, for which PPEs obtained in Denmark were used (Nielsen 2004). Using Danish PPE values for these taxa has been shown to provide vegetation estimates more comparable to observed vegetation (Hellman et al. 2008a). In the modern landscape, these 26 taxa represent about 70-90\% of the total vegetation cover in the upland area of southern Sweden (Broström et al. 2004). The fall speed for each pollen type and the variances of PPEs were obtained from the literature (Eisenhut 1961; Sugita et al. 1999; Broström et al. 2004; Nielsen 2004; Broström et al. 2008). As we combined a set of PPEs from different studies, the covariance matrix between taxa was set to zero for each taxon. We used the mean radius of Fiolen calculated at $714 \mathrm{~m}$ inferred from the total area of the lake surface. We used the pollen dispersal-deposition function appropriate for lakes, which assumes that pollen grains deposited on a lake surface are totally mixed and evenly deposited on the basin floor (Sugita 1993). Standard errors for the estimates of regional vegetation abundance were calculated in the REVEALS program using a hybrid of the delta method (Stuart and Ord 1994) and Monte Carlo simulations (Sugita 2007a). Wind speed was set to $3 \mathrm{~m} \mathrm{~s}^{-1}$.

The vegetation area represented by pollen in large lakes ( $>100 \mathrm{ha}$ ), that is the area from where $95 \%$ of all pollen is derived, is estimated to be within a ca. 100-400 km radius (Sugita 2007a). In southern Sweden simulations applying the concept of 'characteristic radius', assuming homogeneous vegetation, estimate that $65-95 \%$ of the pollen composition (for 25 taxa in a lake with a $950 \mathrm{~m}$ radius) originate from vegetation within a $50 \mathrm{~km}$ radius (Prentice 1988; Sugita 1993; Hellman et al. 2008a). We therefore estimate that our REVEALS reconstruction represents an area of at least a $50 \mathrm{~km}$ radius from Fiolen. Consequently, the maximum spatial extent of the regional vegetation $\left(z_{\max }\right)$ was set to a $50 \mathrm{~km}$ radius in the REVEALS program.

\section{Population data}

Population data for the last ca. 200 years where compiled from a database for all 92 parishes located within a $50 \mathrm{~km}$ radius from Fiolen (http://www.ddb.umu.se/). For this region we calculated both the total population and an estimate of the rural population by excluding the five largest parishes containing towns and/or large villages.

\section{Results}

\section{Chronology}

The age/depth model is based on ${ }^{210} \mathrm{~Pb}$ measurements from the combined profile from the two overlapping cores (Fig. 2a). The correlations between the upper and lower cores were accomplished by using mineral magnetic and $\mathrm{X}$-ray fluorescence records (Fig. 2b, d). The overlap was also confirmed by unsupported ${ }^{210} \mathrm{~Pb}$, detected in both cores, which is only found in sediments younger than ca. 150 years (Fig. 2d). Parts of the chronology were confirmed with chronological markers (isochrones) such as peaks in total lead concentrations and SCP (Fig. 2b, c). A rise in total lead concentration around 1950 and a peak during the 1970s have been recorded in various lake sediments in Sweden, and are related to lead used in industry and petrol (Brännvall et al. 2001; Renberg et al. 2001). SCP records from the same region show a similar pattern, with a rise around 1950 and a peak at 1970. Moreover, the presence of SCP in the lower part of the sediment sequence 

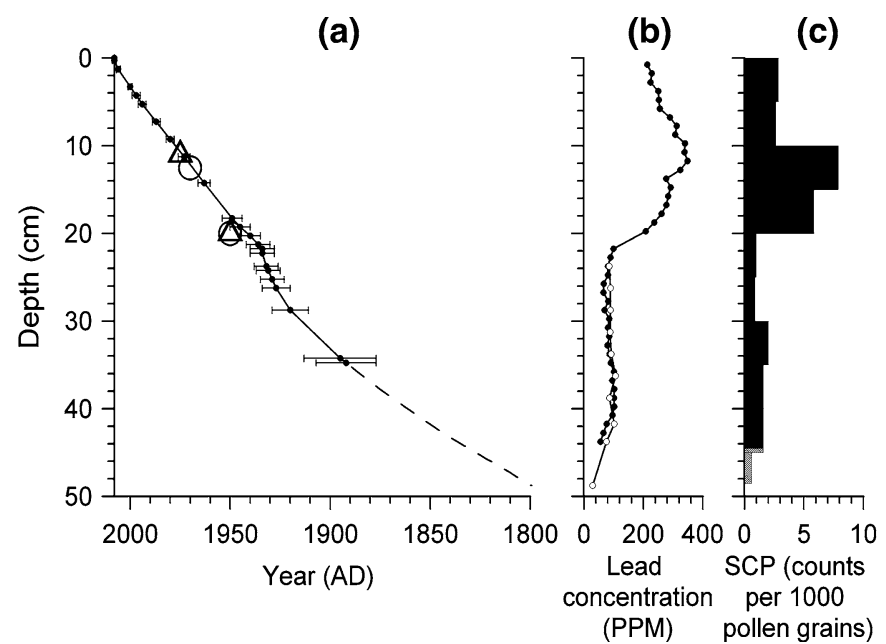

(d)

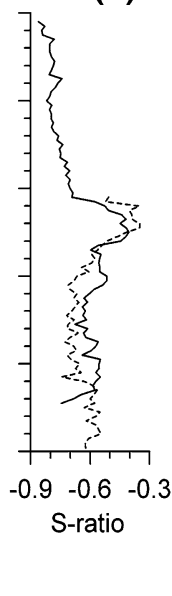

(e)

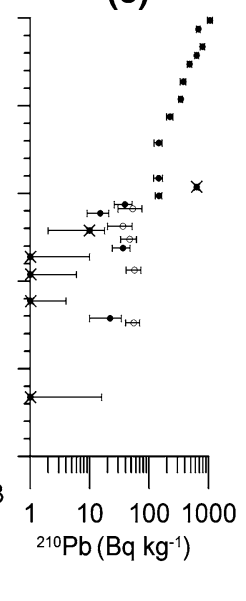

Fig. 2 a Age/depth model used in this study; b total lead concentrations measured on upper core (filled circles) and lower core (open circles); c Spheroidal carbonaceous particles (SCP) counts from upper core (filled bars) and lower core (diagonal lines); d mineral magnetism (S-ratio) measured on upper core (filled line) and lower core (dashed line); e, unsupported ${ }^{210} \mathrm{~Pb}$ concentrations measured on

constrains this part to the 19th century (Wik and Renberg 1996). Based on the obtained chronology, the sedimentation rate was calculated to be $1-8 \mathrm{~mm} /$ year in the uppermost part $(0-48 \mathrm{~cm})$ of the sediment sequence.

Land cover, land use and floristic diversity

The record of terrestrial pollen includes 16 tree, 41 herb and 7 spore taxa. Vegetation coverage was quantified using REVEALS for the 25 taxa (14 trees and 11 herbs) for which PPE are available, representing ca. $77-89 \%$ of the total number of pollen and spores counted $(1,220-1,882$ pollen for each time interval).

The pollen percentage data and the REVEALS reconstructions of vegetation show the same trends of change between 1800 and 2008, although plant abundances differ, which reflects corrections by REVEALS for differences in pollen productivity and dispersal characteristics etc. (Fig. 3). The comparison between pollen percentages and REVEALS estimates show that Picea, Acer, Corylus, Fagus, Poaceae, Cerealia type, Carpinus, Fraxinus, Salix, Tilia, Ulmus, Calluna vulgaris, Asteraceae SF. Cichorioideae, Cyperaceae, Plantago lanceolata and Secale type are underestimated in pollen percentages, while Pinus, Alnus, Betula, Quercus, Juniperus, Calluna vulgaris, Filipendula, Ranunculus acris type and Rumex acetosa type are overestimated in the pollen record (Fig. 3).

Landscape openness based on herb taxa coverage, dominated by Poaceae, in our REVEALS reconstruction varies between 11 and $27 \%$ throughout the studied period. If we include the shrubs Corylus and Juniperus among the upper core (filled circles) and lower core (open circles), based on the sediment sequence from Fiolen. Outliers in the ${ }^{210} \mathrm{~Pb}$ measurements are marked with $\mathrm{X}$. To validate the chronology a rise and peak in total lead concentration (circles) and SCP counts (triangles) are marked on the age/depth curve

open land taxa, assuming that they were growing mainly on grazed areas, openness varies between 16 and $45 \%$ with highest values in the period $1800-1920$ and decreases thereafter. Using the same assumptions, the total tree cover increased from 65 to $84 \%$ in the period $1800-2008$, mainly because of a significant increase in Picea and to some extent Fagus, while Betula, Carpinus, Fraxinus, Salix, Tilia and Ulmus show decreasing trends (Fig. 3).

Palynological richness, as estimated using rarefaction, and based on all terrestrial taxa (16 trees, 41 herbs and 7 ferns), shows that the estimated number of pollen taxa for each time window varies between 25 and 34 during the period studied. The number of taxa increased in the 19th century and varied between 28 and 34 during the 20th century (Figs. 4, 5). REVEALS-based evenness for 14 tree and 11 herb taxa varies between 0.83 and 0.51 during the time 1800-2008, with highest evenness during the 19th century and successive decrease until today. In comparison, both calculations of palynological evenness based on the raw pollen counts show a much smaller variation and to some extent a different pattern than the REVEALS-based evenness. The palynological evenness is $0.57-0.69$ and $0.56-0.66$ throughout the period studied, based on 25 and 64 taxa, respectively (Fig. 4).

According to the REVEALS reconstruction, the main vegetation changes during the last 200 years occurred within an interval of 60 years, 1880-1940, which we interpret as the transition from a traditional to a modern land-use management. This is in agreement with the general history of agricultural development in Sweden, which may vary somewhat regionally (Morell 2001). We 

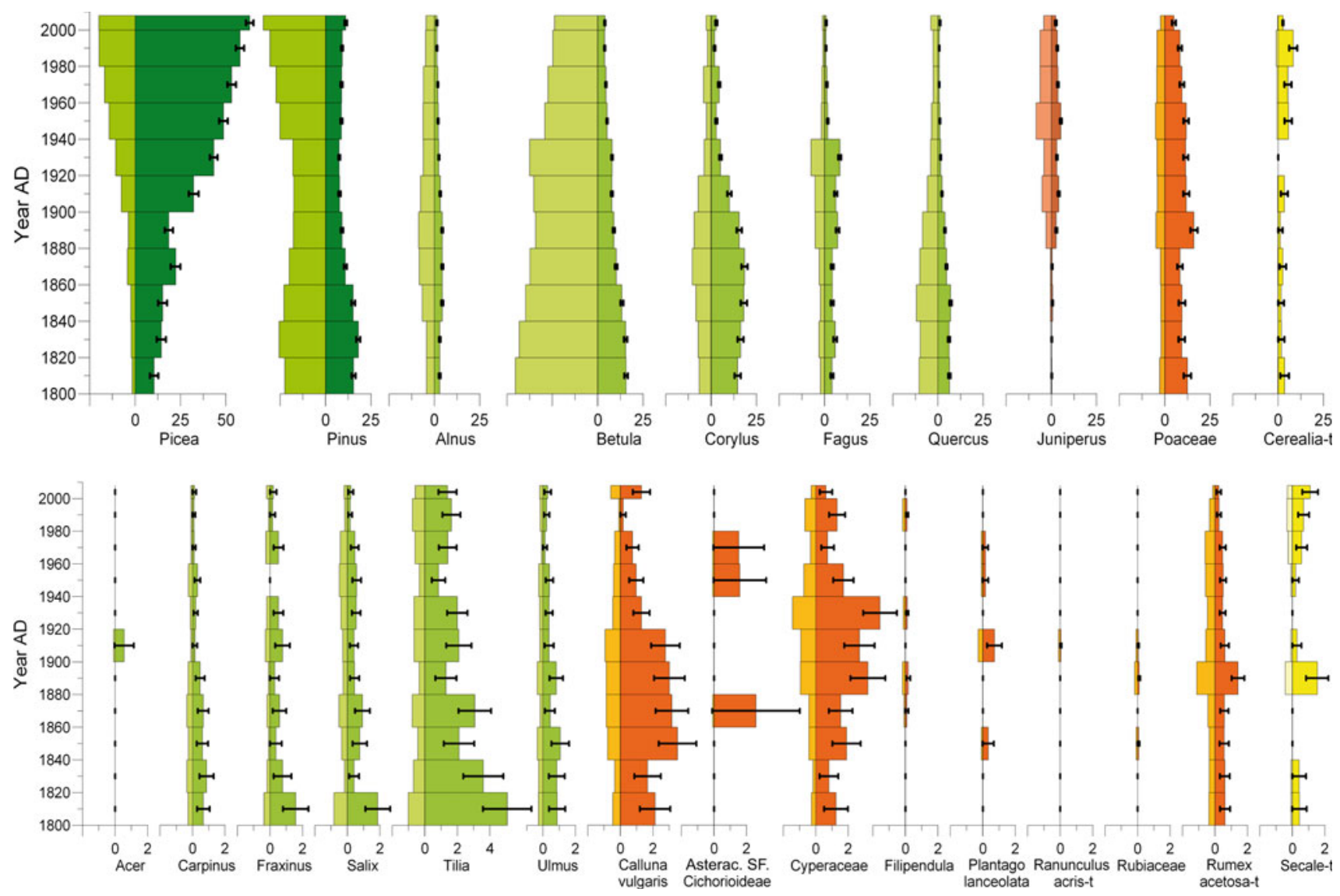

Fig. 3 Pollen percentage diagram (left side) and estimated regional vegetation cover using the REVEALS model (right side) for 25 taxa for the period A.D. 1800-2008 based on the fossil pollen sequence from Fiolen. Note the different scales for the upper and lower parts of the figure

therefore divided the studied time interval into three major land-use periods, corresponding to before, during and after this major land-use reorganization: traditional land-use (1800-1880), transition period (1880-1940) and modern land-use (1940-2008). The transition period was further subdivided into three phases (Phase 1-3), each phase representing changes in vegetation composition and/or floristic diversity (Figs. 3, 4). Thirty-three generalist taxa occurred in all time periods and 31 taxa were found exclusively in one or two land-use periods (Figs. 3, 5).

During the traditional land-use period (1800-1880) the tree cover was $62-69 \%$ and dominated by Betula, Pinus and Picea, while open land covered $31-38 \%$ and was dominated by Corylus and Poaceae (Fig. 3). The abundance of Calluna vulgaris was highest during this period. Palynological richness was $25-31$ and seven herb taxa (Caryophyllaceae, Cichorium intybus type, Crassulaceae, Plantago major, Rosaceae, Trollius europaeus and Polypodium vulgare) are unique to this period (Fig. 5). The relatively high REVEALS-based evenness (0.83-0.79) during this period indicates a more equal abundance of taxa present, compared to later periods (Fig. 4).
In the transition period (1880-1940) the tree cover was 55-75\% with significantly increased abundance of Picea and Fagus, and the coverage of open land taxa, mainly Corylus, decreased. However, herb taxa abundance, especially of Poaceae and Rumex acetosa type, as well as palynological richness increased significantly during the first 20-40 years of the period followed by a significant decrease (Figs. 3, 4). Ten herb taxa, Acer, Alchemilla type, Ambrosia type, Anemona nemorosa group, Frangula alnus, Geum, Lycopodium selago, Phragmites, Ranunculaceae and Torilis japonica, were unique to this period and three taxa, Galium type, Rhinanthus type and Veronica type, which were also present in the traditional land-use, persisted (Figs. 4, 5). REVEALS-based evenness declined from 0.80 to 0.69 during this 60 year long period (Fig. 4). In Phase 1 Juniperus, Poaceae and Secale increased significantly. In Phase 2 Juniperus increased and Poaceae decreased significantly. In Phase 3 Calluna vulgaris decreased significantly.

In the modern land-use period (1940-2008), the tree cover expanded from 69 to $84 \%$ and open land shrank from 31 to $16 \%$, with, however, a significant increase in arable land taxa. 


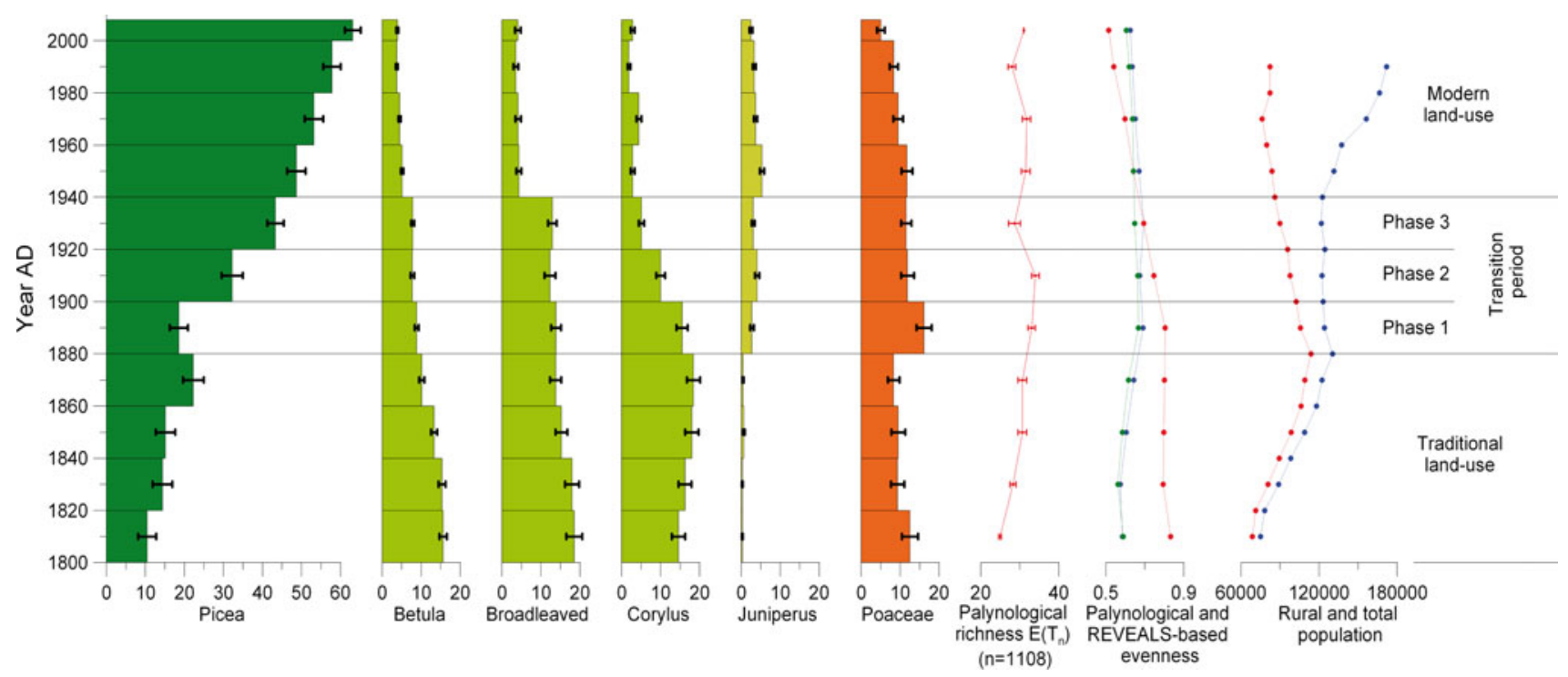

Fig. 4 Regional vegetation estimates for selected taxa, palynological richness, REVEALS-based evenness (red line) and palynological evenness (blue line 25 taxa, green line 64 taxa) based on the Fiolen fossil pollen record, compared to regional rural (red line) and total (blue line) population change A.D. 1800-2008. We divided the sequence into three major land-use periods: traditional land-use 1800-1880, transition period 1880-1940 and modern land-use 1940-2008. Within the transition period we identified three different succession phases

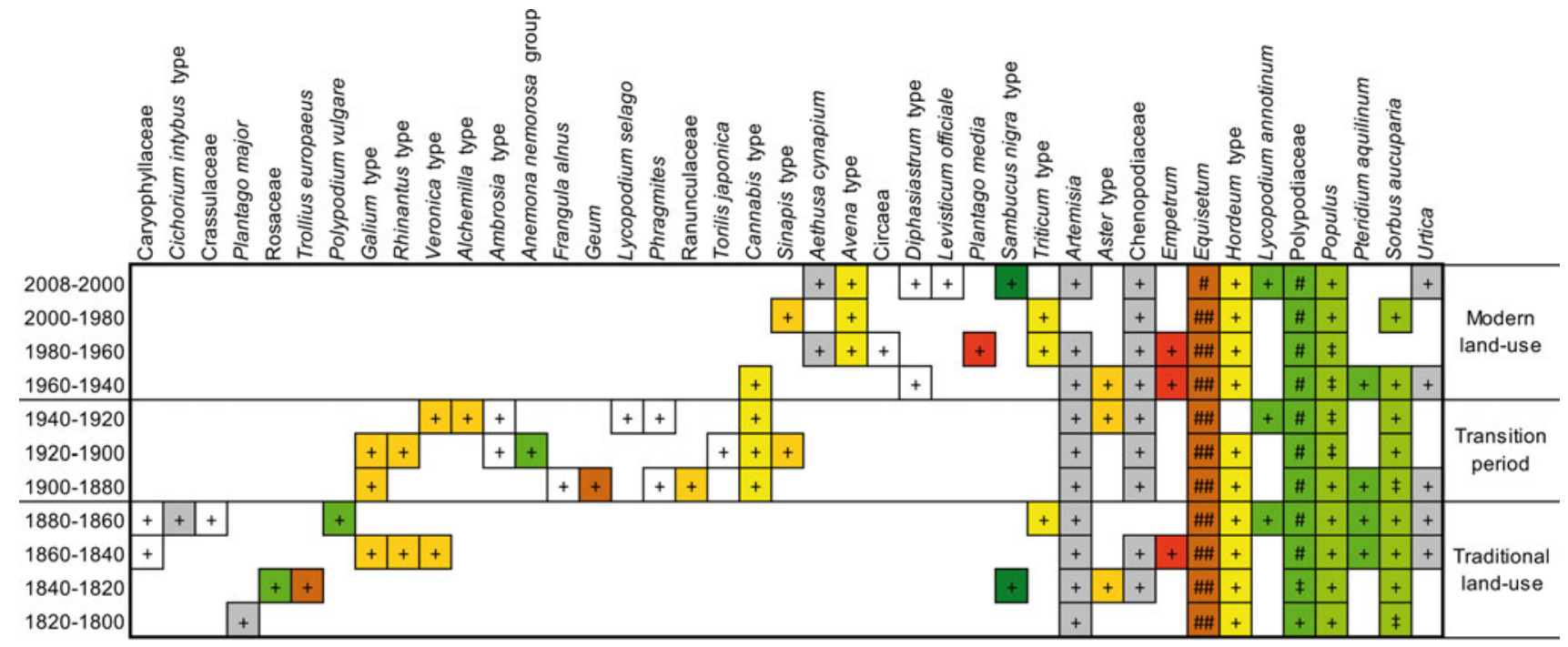

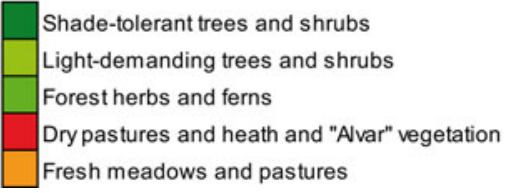

Fig. 5 Terrestrial taxa in the Fiolen pollen record (except those already presented in the REVEALS reconstruction in Fig. 3) divided by their occurrence in relation to land-used periods, traditional landuse A.D. 1800-1880, transition period 1880-1940 and modern land-

At the beginning of this period broadleaved trees, mainly Fagus and Betula, decreased significantly. Palynological richness was 32-28 and six taxa, Aethusa cynapium, Avena
Wet meadows and salt meadows

Ruderal communities

Cultivated land

Not classified

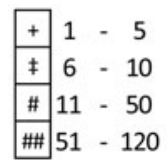

use 1940-2008. The symbols represent the number of pollen grains counted for each time period and the colours represent which land-use type each taxon is associated with according to Berglund (1991)

type, Circaea, Diphasiastrum type, Levisticum officiale and Triticum type, were unique to this period. REVEALS-based evenness continued to decrease from 0.64 to 0.51 . 


\section{Discussion}

Long-term ecological analysis

The high REVEALS-based evenness found in traditional land-use and in the first part of the transition period (1800-1900) (0.79-0.83) suggests that the taxa were more equal in abundance compared to later periods. According to the classification system by Berglund (1991), taxa related to meadows and pastures were also more common in the traditional land-use and transition periods (Galium type, Rhinanthus type, Veronica type, Alchemilla type, Ranunculaceae, Sinapis type and Aster type) than in the modern land-use period (Sinapis type and Aster type). Three rare taxa associated with meadows and pastures (Galium type, Rhinanthus type and Veronica type) found in the traditional land-use period persisted into the transition period despite altered land-use, suggesting that these taxa were favoured by this land-use change. The decline in REVEALS-based evenness in the second part of the transition period and the modern land-use period (0.75-0.51) probably reflects an increased dominance in coverage by fewer habitat types throughout the 20th century. Our study supports this by the increased dominance of Picea throughout the 20th century (32-63\% coverage) and a decrease in open land indicated by a decrease in Corylus (10-3\% coverage) and broadleaved trees (12-4\% coverage) which partly grew in the meadows (Ekstam and Forshed 2000; Morell 2001). A continuous decrease in hay meadows from the late 19th century to the present time is in accordance with the general development in northwest Europe (Bernes 1994; Ekstam and Forshed 2000; Morell 2001; MA 2005; Poschlod et al. 2005; Plieninger 2006). Because hay meadows are associated with high species richness, this implies a general decrease in diversity throughout the 20th century (Ekstam and Forshed 2000). The palynological richness in our study, however, only partly supports this general decline in floristic diversity.

The increase in Juniperus (0.4-3\% coverage), Poaceae (8-16\% coverage) and palynological richness (31-33) at the beginning of the transition period (1880-1900, Phase 1) coincides with a time period when people started to abandon the countryside in favour of towns at the end of the 19th century (Andersson Palm 2000), which suggests that these changes can be indicative of reduced traditional management. Consequently, the increase in Poaceae and many herbs does not necessarily indicate an areal expansion of these taxa, as suggested by the REVEALS reconstruction, but rather an increase in biomass, when grazing and mowing were reduced and grasses and herbs could flower (Groenman-van Waateringe 1993). Studies have shown that the floristic diversity of present day grasslands may increase initially after abandonment (Ekstam and Forshed 1992; Bernes 1994). An alternative interpretation is that the increase in Poaceae and palynological richness actually represents an increase in grass and herb coverage, either due to an increase in grasslands and/or areas of grass cultivation. However, the significant decrease in Corylus at the same time indicates a greater proportion of trees in the landscape and therefore less flowering of Corylus (Fyfe et al. 2008). Furthermore, an increase in grass cultivation is more likely to favour an increase only in Poaceae and not floristic richness. In contrast, we suggest that the increase in Juniperus at the beginning of the transition period represents an areal expansion of juniper, as suggested by the REVEALS reconstruction. Juniperus may have been suppressed before the end of the 19th century by intense grazing and could expand when the grazing pressure decreased, something that has been observed in other regions in Sweden during recent decades (Rosén 1988).

In the second 20-year interval of the transition period (1900-1920, Phase 2) the palynological richness remained at a higher level (34) and REVEALS-based evenness decreased (0.80-0.75), which probably represents the increased importance of forestry and a continued reduction in the extent of traditional land-use management. This is indicated in our study mainly by the increase in Picea (19-32\% coverage) and the decrease in Corylus (15-10\% coverage), while several herb taxa (Alchemilla type, Ambrosia type, Anemona nemorosa group, Frangula alnus, Geum, Lycopodium selago, Ranunculaceae and Torilis japonica) were favoured during succession from open towards more tree cover habitats (Figs. 4, 5). The common lands, that consisted of a mixture of open grasslands and grazed woodland, became more economically important for forestry in the second part of the 19th century, and Picea could expand in these areas when the land was divided between individual farmers in connection with the land reform (Laga Skifte) (Ekstam and Forshed 2000; Gadd 2000; Morell 2001; Eliasson 2002). Moreover, the first forestry legislation in 1903 favoured plantation of forest (Eliasson 2002). Reforestation during the 20th century has previously been observed qualitatively, but never quantified, however in pollen diagrams from the upland area in southern Sweden (Björkman 1996; Lagerås 1996; Lindbladh 1999; Lagerås 2007; Greisman 2009; Sköld et al. 2010).

The palynological richness shows the highest values (33-34) in the period 1880-1920 (phases 1 and 2), which suggests that floristic diversity was favoured in the first 40 years in the transition from a traditional to a modern land-use management. However, at the end of the transition period (phase 3), palynological richness is reduced to lower values (29), which indicates that floristic richness was only favoured during the transition for a limited time (40 years). The decrease in REVEALS-based evenness in transition phase $3(0.75-0.69)$ reflects expanding woodlands, and the landscape became dominated by fewer taxa. We interpret 
the decrease in Corylus as a sign of reduction in open areas, as it is known to have fewer flowers when growing in woods compared to open areas (Fyfe et al. 2008). At the end of the transition period (1940), the broadleaved trees were probably cut down in favour of spruce plantation. We interpret the decrease of early successional tree taxa like Betula (8-5\% coverage) at this time as an effect of more than ca. 60 years of reduced traditional land-use management and that it was replaced by Picea (Morell 2001).

The transition from a traditional to a modern land-use management was made possible by a number of changes in society at this time. Some of the most important changes in agriculture were the introduction of artificial fertilizers and grass cultivation that started around the middle of the 19th century in northern Europe (Myrdal 1997; Morell 2001). This led to the previously important nutrient balance in the agricultural system becoming unnecessary, that is the balance between the area of meadows for hay production, number of animals for manure production and the extent of cultivated fields (Myrdal 1997; Morell 2001; Poschlod et al. 2005). Overall this led to urbanisation and to a higher degree of specialisation within agriculture and forestry (Morell 2001; Poschlod et al. 2005).

In the modern land-use period the degree of change in vegetation was slower compared to the transition period, particularly as the abundance of deciduous taxa remains almost constant (11-9\% coverage). The REVEALS-based evenness shows the lowest values $(0.64-0.51)$ in the modern land-use period compared to earlier ones, indicating an increased dominance by fewer taxa in the region. The Cerealia coverage is in general higher (3-8\% coverage) during the modern land-use period, which suggests an expansion of cultivated fields during this period. At the same time, pollen taxa related to meadows and pastures decrease from seven to two (Fig. 5; Berglund 1991). These results show an overall development towards a modern land-use, with farms that became specialised in one kind of land-use, such as forestry or arable.

\section{Methodology}

A robust chronology is crucial for long-term ecological analysis and for comparison with specific historical events. Central to our chronology are the $\mathrm{Pb}^{210}$ measurements with subsequent CRS modelling, confirmed by chronological markers (SCP and total lead concentrations). A potential weak point is the overlap between the sediment cores, which was overcome by matching the mineral magnetic, XRF and the $\mathrm{Pb}^{210}$ records. Another potential weak point is the extrapolation of the chronology to the lower part. However, this was overcome by the low counts of SCP related to fossil fuel combustion, which limit this part of the sediment sequence to the 19th century.
Based on pollen counts, the REVEALS model has been used to quantify the land-cover changes within a specified area and, since error estimates are included in the REVEALS estimates, it is possible to identify significant changes which serve as more objective interpretations. We have used fossil pollen data from one large lake ( $>100 \mathrm{ha}$ ) that should be sufficient to describe the regional vegetation cover (Sugita 1994, 2007a; Hellman et al. 2008b). However, there may be variations between and within lakes for specific time intervals depending on factors such as where the sediment sequences were retrieved or how accurate the chronologies are. Therefore, if possible, the use of fossil pollen counts from more than one lake sediment sequence is preferable when estimating the regional vegetation using the REVEALS model (Sugita 2007a; Hellman et al. 2008b). Based on the REVEALS output we have interpreted land-use changes throughout the studied period. However, at the beginning of the transition period, we suggest that the increase in grasses and herbs represents an increase in representation rather than an increase in vegetation. This increase is therefore related to pollen productivity in response to different grazing/mowing pressures, which makes the interpretation complicated, using the REVEALS output for these taxa. Poaceae includes a large group of taxa that may react differently to land-use changes (Broström et al. 2008).

We have used palynological richness and rarefaction analysis in this study as a proxy for floristic richness. However, there are a number of potential biases related to pollen richness, for instance many taxa produce small amounts of pollen and are more or less found by chance in the pollen record (Odgaard 2007). Basin size may also influence representation of low pollen producers and dispersers. The relatively large size of the lake used in this study may therefore explain the relatively small changes that we recorded in palynological richness. Furthermore, changes in vegetation composition may affect the total pollen productivity, which in turn may affect the likelihood that rare grains are found in a pollen assemblage (Odgaard 1999; Peros and Gajewski 2008; van der Knaap 2009). In our study, for example, the increase in Picea coverage during the 20th century should in theory decrease the total pollen productivity, because Picea is a low pollen producer compared to many other taxa that were more common during the 19th century, such as Betula and Quercus (Broström et al. 2008). Therefore, a larger number of pollen taxa might have been found in some of the pollen samples, but for this change in vegetation composition. This could explain the relatively small variation in palynological richness in our study during the 20th century despite large changes in land-use (Odgaard 1999).

To reconstruct past evenness we have used the ratio between the Shannon index and maximum evenness, which may be used as a measure of plant evenness (Magurran 2004; Odgaard 2007). However, using the pollen composition in a sample (palynological evenness) to reconstruct past 
evenness is related to a number of biases relating to how the surrounding vegetation is represented by the pollen record (Odgaard 1999, 2007). Therefore, the observed changes in palynological evenness are difficult to interpret. In contrast, the corrected vegetation proportions estimated by the REVEALS model are much easier to use, because the pollen composition has been corrected for all major biases related to pollen dispersal and deposition (Sugita 2007a). Consequently, we argue that the REVEALS-based evenness is at present the most appropriate method to reconstruct past evenness. The limitation is that we are restricted to taxa for which pollen productivity data are available.

\section{Contribution to ecosystem management}

Anton et al. (2010) listed the evaluation of the effect of agriculture and forestry practices on biodiversity and ecosystem services as one of the future research needs for EU biodiversity conservancy policy. In this study we have developed and applied a palaeoecological methodology for long-term ecological analysis of these effects at a regional scale in the transition from traditional to modern land-use using the uplands of southern Sweden as an example. The results give support to a more dynamic ecosystem management approach, suggested by Emanuelsson (2005) and Haslett et al. (2010). In this example we have identified a transition period of ca. 60 years between traditional and modern land-use management and provided an estimate of transition time that promotes floristic diversity of ca. 40 years. These estimates are of course dependent on the temporal resolution and may vary between study areas. We have recorded the transition in further detail in three phases with an initial increase in open land vegetation followed by a decline in deciduous taxa that are successively replaced by Picea. The estimates of past REVEALS-based evenness provide a clearer picture of how the abundance of various taxa changed from relatively low abundance of many taxa in the traditional land-use period to a few dominant taxa in modern land-use. Our results encourage the use of a palaeoecological methodology to give reasonable estimates of spatial and temporal change useful for ecosystem management that promotes floristic diversity. This methodological approach and study design has the potential to be used in other study areas, anywhere where PPEs exist and/ or for other land-use transition periods on both regional and local scales.

\section{Conclusions}

- The long-term ecological analysis of the transition from traditional to modern land-use from 1800-2008 shows an increase in total tree cover (65-84\%) and change of tree composition from deciduous to coniferous dominance. Within the shrinking area of open land (35-16\%), arable land taxa expanded while the number and coverage of herbs in the remaining grasslands decreased. We identified a transition period of 60 years between 1880 and 1940 when the main vegetation changes occurred.

- Our results suggest that the succession from open grasslands to more tree-covered habitats initially favours floristic richness, which, in this study, is indicated by palynological richness that reached its highest values during the first 40 years of the transition period. The highest REVEALS-based evenness was recorded in traditional land-use and at the beginning of the transition period, reflecting a more equal abundance of different habitats compared to later periods. A decrease in pollen taxa related to meadows and pastures in the modern land-use period suggests a decrease in the extent of these land-use types during this period.

- We have developed a study design to quantify spatial and temporal change in land-use and floristic diversity. This requires application of the REVEALS model and a robust chronology. For the first time a more complete reconstruction of past floristic diversity using the two components, richness and evenness, has been possible.

- Our long-term ecological analysis supports a more dynamic ecosystem management, which alternates between periods of traditional land-use and phases of succession ( $<40$ years). We encourage the use of palaeoecological methodology to provide concrete estimates of land-use change that promotes floristic diversity. Our study design may be used in other study areas, for other land-use transition periods and/or on regional and local scales.

Acknowledgements Ian Snowball is acknowledged for help during fieldwork, Shinya Sugita for inputs on quantitative vegetation reconstruction, John Boyle for help with XRF measurements, and the LANDCLIM network for providing a forum for discussions which helped to put this work in a larger context. We thank Martin Sykes and Margaret Sykes for comments and corrections that improved the manuscript. This study was supported by grants from The Swedish Research Council Formas, Helge Ax:son Johnson Foundation, Royal Physiographic Society in Lund and The Swedish Foundation for International Cooperation in Research and Higher Education.

Open Access This article is distributed under the terms of the Creative Commons Attribution License which permits any use, distribution, and reproduction in any medium, provided the original author(s) and the source are credited.

\section{References}

Andersen ST (1970) The relative pollen productivity and pollen representation of north European trees, and correction factors for tree pollen spectra. Dan Geol Unders 96:1-99 
Andersson Palm L (2000) Folkmängden i Sveriges socknar och kommuner 1571-1997. Books-on-Demand, Göteborg

Anton C, Young J, Harrison PA, Musche M, Bela G, Feld CK, Harrington R, Haslett JR, Pataki G, Rounsevell MDA, Skourtos M, Sousa JP, Sykes MT, Tinch R, Vandewalle M, Watt A, Settele J (2010) Research needs for incorporating the ecosystem service approach into EU biodiversity conservation policy. Biodivers Conserv 19:2,979-2,994

Appleby PG (2001) Chronostratigraphic techniques in recent sediments. In: Last WM, Smol JP (eds) Tracking environmental change using lake sediments. Springer, Dordrecht, pp 171-203

Autio J, Hicks S (2004) Annual variations in pollen deposition and meteorological conditions on the fell Aakenustunturi in northern Finland: Potential for using fossil pollen as climate proxy. Grana 43:31-47

Bender O, Boehmer HJ, Jens D, Schumacher KP (2005) Analysis of landuse change in a sector of upper Franconia (Bavaria, Germany) since 1850 using land register records. Landsc Ecol 20:149-163

Berglund BE (1991) The cultural landscape during 6000 years in southern Sweden. Ecol Bull. Munksgaard, Copenhagen

Berglund BE, Ralska-Jasiewiczowa M (1986) Handbook of Holocene palaeoecology and palaeohydrology. Wiley, New York

Berglund BE, Lagerås P, Regnéll J (2002) Odlingslandskapets historia i Sydsverige-en pollenanalytisk syntes. In: Berglund BE, Börjesson K (eds) Markens minnen. Swedish National Heritage Board, Stockholm, pp 150-169

Berglund BE, Persson T, Björkman L (2008) Late Quaternary landscape and vegetation diversity in a north European perspective. Quat Int 184:187-194

Bernes C (1994) Biological diversity in Sweden - a country study. Swedish Environmental Protection Agency, Solna

Beug H-J (1961) Leitfaden der Pollenbestimmung, Lieferung 1. Fischer, Stuttgart

Beug H-J (2004) Leitfaden der Pollenbestimmung für Mitteleuropa und angrenzende Gebiete. Pfeil, München

Birks HJB, Line JM (1992) The use of rarefaction analysis for estimating palynological richness from Quaternary pollen-analytical data. Holocene 2:1-10

Björkman L (1996) The Late Holocene history of beech Fagus sylvatica and Norway spruce Picea abies at stand-scale in southern Sweden. Dissertation, Lund University

Bradshaw RHW, Webb T (1985) Relationships between contemporary pollen and vegetation data from Wisconsin and Michigan, USA. Ecology 66:721-737

Brännvall M-L, Bindler R, Emteryd O, Renberg I (2001) Four thousand years of atmospheric lead pollution in northern Europe: A summary from Swedish lake sediments. J Paleolimnol 25:421-435

Broström A, Gaillard M-J, Ihse M, Odgaard B (1998) Pollenlandscape relationship in modern analogues of ancient cultural landscapes in southern Sweden - a first step towards quantification of vegetation openness in the past. Veget Hist Archaeobot 7:189-201

Broström A, Sugita S, Gaillard M-J (2004) Pollen productivity estimates for the reconstruction of past vegetation cover in the cultural landscape of southern Sweden. Holocene 14:368-381

Broström A, Nielsen AB, Gaillard M-J, Hjelle K, Mazier F, Binney H, Bunting J, Fyfe R, Meltsov V, Poska A, Räsänen S, Soepboer W, Von Stedingk H, Suutari H, Sugita S (2008) Pollen productivity estimates of key European plant taxa for quantitative reconstruction of past vegetation: a review. Veget Hist Archaeobot 17:461-478

Calcote R (1995) Source area and pollen productivity: Evidence from forest hollows. J Ecol 83:591-602

Dahlström A, Hallgren K (2008) Naturbetesmarkers och slåtterängars historiska markanvändning kring 1850. In: Blom S (ed)
Utveckling av ängs- och betesmarker - igår, idag och imorgon. Jordbruksverket, Jönköping

Davis MB (1963) On the theory of pollen analysis. Am J Sci 261: 897-912

Davis MB (2000) Palynology after Y2K - understanding the source area of pollen in sediments. Annu Rev Earth Planet Sci 28:1-18

Dawson TP, Jackson ST, House JI, Prentice IC, Mace GM (2011) Beyond predictions: biodiversity conservation in a changing climate. Science 332:53-58

Eisenhut G (1961) Untersuchungen über die Morphologie und Ökologie der Pollenkörner heimischer und fremdländischer Waldbäume. Parey, Hamburg

Ekstam U, Forshed N (1992) Om hävden upphör. Kärlväxter som indikatorarter i ängs- och hagmarker. Naturvårdsverket, Solna

Ekstam U, Forshed N (2000) Svenska naturbetesmarker - historia och ekologi. Naturvårdsverket, Stockholm

Eliasson P (2002) Skog, makt och människor. En miljöhistoria om svensk skog 1800-1875. Dissertation, Lund University

Emanuelsson U (2005) Ohävd—en nödvändig hävd. In: Bunte C (ed) Arkeologi och naturvetenskap. Gyllenstiernska Krapperupstiftelsen. Gyllenstiernska Krapperupstiftelsen, Nyhamnsläge, pp 111-128.

Emanuelsson U (2009) The rural landscapes of Europe - How man has shaped European nature. Formas, Stockholm

Eriksson O, Cousins S, Bruun HH (2002) Land-use history and fragmentation of traditionally managed grasslands in Scandinavia. J Veget Sci 13:743-748

Fredén C (ed) (1994) Geology. National atlas of Sweden, SNA, Stockholm

Fyfe RM, Brück J, Johnston R, Lewis H, Roland TP, Wickstead H (2008) Historical context and chronology of Bronze Age land enclosure on Dartmoor, UK. J Archaeol Sci 35:2,250-2,261

Gadd C-J (2000) Den agrara revolutionen 1700-1870. Natur och Kultur/LTs förlag, Stockholm

Gaillard M-J, Sugita S, Mazier F, Trondman A-K, Broström A, Hickler T, Kaplan JO, Kjellström E, Kokfelt U, Kuneš P, Lemmen C, Miller P, Olofsson J, Poska A, Rundgren M, Smith B, Strandberg G, Fyfe R, Nielsen AB, Alenius T, Balakauskas L, Barnekow L, Birks HJB, Bjune A, Björkman L, Giesecke T, Hjelle K, Kalnina L, Kangur M, Van Der Knaap WO, Koff T, Lagerås $\mathrm{P}$, Latałowa $\mathrm{M}$, Leydet $\mathrm{M}$, Lechterbeck J, Lindbladh M, Odgaard BV, Peglar S, Segerström U, Von Stedingk H, Seppä H (2010) Holocene land-cover reconstructions for studies on land cover-climate feedbacks. Clim Past Discuss 6:483-499

Greisman A (2009) The role of fire and human impact in Holocene forest and landscape dynamics of the Boreo-nemorial zone of southern Sweden. Dissertation, University of Kalmar

Groenman-Van Waateringe W (1993) The effects of grazing on the pollen production of grasses. Veget Hist Archaeobot 2:157-162

Harrison PA, Vandewalle M, Sykes MT, Berry PM, Bugter R, De Bello F, Feld CK, Grandin U, Harrington R, Haslett JR, Jongman RHG, Luck GW, Da Silva PM, Moora M, Settele J, Sousa JP, Zobel M (2010) Identifying and prioritising services in European terrestrial and freshwater ecosystems. Biodivers Conserv 19: $2,791-2,821$

Haslett JR, Berry PM, Bela G, Jongman RHG, Pataki G, Samways MJ, Zobel M (2010) Changing conservation strategies in Europe: A framework integrating ecosystem services and dynamics. Biodivers Conserv 19:2,963-2,977

Hellman S, Gaillard M-J, Broström A, Sugita S (2008a) Effects of the sampling design and selection of parameter values on pollenbased quantitative reconstructions of regional vegetation: a case study in southern Sweden using the REVEALS model. Veget Hist Archaeobot 17:445-459

Hellman S, Gaillard M-J, Broström A, Sugita S (2008b) The REVEALS model, a new tool to estimate past regional plant abundance from pollen data in large lakes: Validation in southern Sweden. J Quat Sci 23:21-42 
Hellman S, Bunting J, Gaillard M-J (2009) Relevant source area of pollen in patchy cultural landscapes and signals of anthropogenic landscape disturbance in the pollen record: a simulation approach. Rev Palaeobot Palynol 153:245-258

Hicks S (1999) The relationship between climate and annual pollen deposition at northern tree-lines. Chemosphere: Glob Change Sci $1: 403-416$

Jackson ST, Hobbs RJ (2009) Ecological restoration in the light of ecological history. Science 325:567-569

Johansson L, Hall K, Prentice HC, Ihse M, Reitalu T, Sykes MT, Kindström M (2008) Semi-natural grassland continuity, long-term land-use change and plant species richness in an agricultural landscape on Öland, Sweden. Landsc Urban Plan 84:200-211

Lagerås P (1996) Vegetation and land-use in the Småland Uplands, southern Sweden, during the last 6000 years. Lund University, Dissertation

Lagerås P (2007) The ecology of expansion and abandonment. Medieval and Post-medieval land-use and settlement dynamics in a landscape perspective. National Heritage Board, Stockholm

Larsson L-O (1980) Småländsk bebyggelsehistoria 1. Från Vikingatid till Vasatid 1:2 Allbo härad. Acta Wexionensia, Växjö

Lindbladh M (1999) The influence of former land-use on vegetation and biodiversity in the boreo-nemoral zone of Sweden. Ecography 22:485-498

Lunt ID, Spooner PG (2005) Using historical ecology to understand patterns of biodiversity in fragmented agricultural landscapes. J Biogeogr 32:1,859-1,873

MA (2005) Ecosystems and human well-being: Synthesis. Millennium ecosystem assessment. Island Press, Washington DC

Magurran AE (2004) Measuring biological diversity. Blackwell, Oxford

Moore PD, Webb JA, Collinson ME (1991) Pollen analysis, 2nd edn. Blackwell, Oxford

Morell M (2001) Jordbruket i industrisamhället 1870-1945. Natur och Kultur/LTs förlag, Stockholm

Myrdal J (1997) En agrarhistorisk syntes. In: Larsson BMP, Morell M, Myrdal J (eds) Agrarhistoria. LTs Förlag, Stockholm

Myrdal J (2003) Digerdöden, pestvågor och ödeläggelse. Ett perspektiv på senmedeltidens Sverige. Sällskapet Runica et Mediævalia, Stockholm

Nielsen AB (2004) Modelling pollen sedimentation in Danish lakes at c. A.D. 1800: An attempt to validate the Pollscape model. J Biogeogr 31:1,693-1,709

Odgaard BV (1994) The Holocene vegetation history of northern west Jutland, Denmark. Council for Nordic Publications in Botany, Copenhagen

Odgaard BV (1999) Fossil pollen as a record of past biodiversity. J Biogeogr 26:7-17

Odgaard BV (2007) Reconstructing past biodiversity development. In: Elias SA (ed) Encyclopedia of Quaternary science. Elsevier, Amsterdam, pp 2,508-2,514

Parsons RW, Prentice IC (1981) Statistical approaches to r-values and the pollen-vegetation relationship. Rev Palaeobot Palynol $32: 127-152$

Peros MC, Gajewski K (2008) Testing the reliability of pollen-based diversity estimates. J Paleolimnol 40:357-368

Plieninger T (2006) Habitat loss, fragmentation, and alteration quantifying the impact of land-use changes on a Spanish Dehesa landscape by use of aerial photography and GIS. Landsc Ecol 21:91-105

Poschlod P, Bakker JP, Kahmen S (2005) Changing land use and its impact on biodiversity. Basic Appl Ecol 6:93-98

Prentice IC (1985) Pollen representation, source area, and basin size: Toward a unified theory of pollen analysis. Quat Res 23:76-86

Prentice IC (1988) Records of vegetation in time and space: the principles of pollen analysis. In: Huntley B, Webb $\mathrm{T}$ (eds) Vegetation history. Kluwer, Dordrecht, pp 17-42
Punt W (1976-2003) The northwest European pollen flora I-VIII. Elsevier, Amsterdam

Raab B, Vedin H (1995) Climate, lakes and rivers. National atlas of Sweden, SNA, Stockholm

Renberg I, Hansson H (2008) The HTH sediment corer. J Paleolimnol 40:655-659

Renberg I, Bindler R, Brännvall M-L (2001) Using the historical atmospheric lead-deposition record as a chronological marker in sediment deposits in Europe. Holocene 11:511-516

Rosén E (1988) Shrub expansion in Alvar grasslands on Öland. Acta Phytogeogr Suec 76:87-100

Sjörs H (1963) Amphi-atlantic zonation, nemoral to arctic. In: Löve A, Löve D (eds) North Atlantic biota and their history. Pergamon, Oxford, pp 109-125

Sköld E, Lagerås P, Berglund BE (2010) Temporal cultural landscape dynamics in a marginal upland area: Agricultural expansions and contractions inferred from palynological evidence at Yttra berg, southern Sweden. Veget Hist Archaeobot 19:121-136

Soepboer W, Sugita S, Lotter AF (2010) Regional vegetation-cover changes on the Swiss plateau during the past two millennia: A pollen-based reconstruction using the REVEALS model. Quat Sci Rev 29:472-483

Stuart A, Ord JK (1994) Kendall's advanced theory of statistics, vol 1. Distribution theory. Arnold, London

Sugita S (1993) A model of pollen source area for an entire lake surface. Quat Res 39:239-244

Sugita S (1994) Pollen representation of vegetation in Quaternary sediments: Theory and method in patchy vegetation. J Ecol 82:881-897

Sugita S (2007a) Theory of quantitative reconstruction of vegetation I: Pollen from large sites REVEALS regional vegetation composition. Holocene 17:229-241

Sugita S (2007b) Theory of quantitative reconstruction of vegetation II: All you need is LOVE. Holocene 17:243-257

Sugita S, Gaillard M-J, Broström A (1999) Landscape openness and pollen records: A simulation approach. Holocene 9:409-421

Sugita S, Gaillard M-J, Hellman S, Broström A (2008) Model-based reconstruction of vegetation and landscape using fossil pollen. In: Posluschny A, Lambers K, Herzog I (eds) Proceedings of the 35th International conference on computer applications and quantitative methods in archaeology. Habelt, Berlin, pp 385-391

Sugita S, Parshall T, Calcote R, Walker K (2010) Testing the landscape reconstruction algorithm for spatially explicit reconstruction of vegetation in northern Michigan and Wisconsin. Quat Res 74:289-300

Thompson R, Oldfield F (1986) Environmental magnetism. Allen and Unwin, London

Thompson R, Bloemendal J, Dearing JA, Oldfield F, Rummery TA, Stober JC, Turner GM (1980) Environmental applications of magnetic measurements. Science 207:481-486

Van der Knaap WO (2009) Estimating pollen diversity from pollen accumulation rates: A method to assess taxonomic richness in the landscape. Holocene 19:159-163

Wik M, Renberg I (1996) Environmental records of carbonaceous flyash particles from fossil-fuel combustion. J Paleolimnol 15: 193-206

Willis KJ, Bhagwat SA (2010) Questions of importance to the conservation of biological diversity: Answers from the past. Clim Past 6:759-769

Willis KJ, Bailey RM, Bhagwat SA, Birks HJB (2010) Biodiversity baselines, thresholds and resilience: Testing predictions and assumptions using palaeoecological data. Trends Ecol Evol 25:583-591

Zimmermann P, Tasser E, Leitinger G, Tappeiner U (2010) Effects of land-use and land-cover pattern on landscape-scale biodiversity in the European Alps. Agric Ecosyst Environ 139:13-22 